Khazanah: Jurnal Studi Islam dan Humaniora

ISSN: 0215-837X (p); 2460-7606 (e), Vol. 18 (1), 2020, pp. 75-90

DOI: 0.18592/khazanah.v18i1.3436

Submit :12/01/2020 Review : 02/06/2020 Publish : 20/06/2020

\title{
THE 'NAFS' (SELF), AS OUTLINED BY EARLY PHILOSOPHERS AND SUFI MYSTICS OF AFGHANISTAN AND IRAN
}

\author{
Homayun Shahpesandy \\ Lincolnshire Partnership Foundation Trust \\ The Hartsholme Centre, Lincoln, LN1 1FS \\ United Kingdom \\ Homayun.shahpesandy@nhs.net
}

\begin{abstract}
The understanding of the self is of paramount significance because as individuals we wonder who we are; where we come from; what the purpose of our life is, and what true happiness and misery entail. Muslim philosophers such as Razi, Farabi and Avicenna as well as Sufi mystics like Sanai, Attar and Rumi believe mankind is composed of an external form or body, and an internal entity, which is one's true substance, 'nafs', self, mind or soul. Sufi mystics likewise the Muslim philosophers believe that mankind is a union of mind and body; nevertheless, they consider the physical body is a deception, as the true essence of buman consists of his soul that is eternal and divine. They emphasize the immortal nature of the soul, created by God that returns through various stages to be in closer proximity to its Creator. They concur "although man is not primordial, he is eternal; while his corpus is terrestrial, his soul is divine; and although his essence is mixed with animal and voracious attributes; if he gets rid of his maleficence, man will reach the proximity of God, which represents its ultimate happiness.
\end{abstract}

Keywords: Nafs; Early Philosophers; Sufi Mistics; Afganistan; Iran

\section{Introduction}

The understanding of the self is of paramount importance, because as individuals we wonder who we are, where we come from, what the purpose of our life is, and what true happiness and misery entail. From a psychological point of view, the self is also defined as a person's distinctive individuality, identity, essential nature, or collection of personal characteristics. ${ }^{1}$ From a sociological perspective, the concept of 'self highlights the reflective and reflexive ability of human beings to take themselves as objects of their own thought. A distinction is drawn between two aspects of the self; the ' $\mathrm{I}$ ' which is spontaneous, inner, creative and subjective; and the 'Me' which is the organised attitudes of others, connects to the wider society, is more social and determined. The 'Me' is often called the self-concept - how people

${ }^{1}$ Andrew M. Colman, A Dictionary of Psychology, Fourth Edition (Oxford: Oxford University Press, 2015), 678. 
see themselves through the eyes of others. ${ }^{2}$ The 'self' has also been defined as a location, rather than a substance or an attribute. The sense of self is located at a point in space, creating a perspective in time and a variety of positions in local moral orders. It is not having an awareness of some kind of being, particularly not an awareness of an entity at the core of one's being. ${ }^{3}$

With regards to the subject of the self, it has indeed been examined by different cultures and religious groups. One of the first descriptions of the self comes from the Upanishad religious scriptures from around 750 Before Christ (BC) that defines self (átman') as the most inner core of human beings, and the ungraspable essence of mankind, 'átman' or soul. ${ }^{4}$ Similarly, in accordance with the Mahavira religion (c. from around $600 \mathrm{BC}$ ), the world (from eternity) consists of animated 'jiva' (soul) and 'ajiva' (matter). The jiva contains the capacity for complete knowledge, moral excellence, and eternal happiness. Nonetheless, as the 'jiva' is, from its very creation being contaminated with 'ajiva' (matter), it cannot materialise this ability. The redemption of 'jiva' from this binding to the matter (physical body) is, therefore, only achieved if the matter ('ajiva') is abolished from the soul ('jiva'). This salvation could be achieved only by a rigorously ascetic life and renouncing physical pleasure. ${ }^{5}$

Heraclitus from Ephesus (c. 6th century BC), is one of the first Greek philosophers who refers to the divine origin of the human soul, calling it "primal fire." Heraclitus also talks about the 'world order' that he calls universal "logos" or knowledge that rules over everything. Man's soul is part of this universal logos, where it will return after his death. ${ }^{6}$

Plato (c. 427-347 BC) is the first from the Gold Age of Greek philosophy who outlined the human soul as tripartite; 'logistikon' or logical (located in the head), "thumetikon" or emotional (located in the heart) and "epithumetikon" or appetitive (located in the stomach). Plato believes only the rational part of the human soul is eternal and originates from the 'soul of the world." Correspondingly, Aristotle (c. 384-322 BC, Stagira, Greece) contemplates the human soul as tripartite, consisting of the vegetative (its functions are nutrition and reproduction), animal (that has abilities of sensual perception and relocation) and human, or rational. For Aristotle, the rational soul is immortal and does not die with the body. Aristotle views the body as the instrument (organ) of the soul. In Aristotle's view, the perfection of each being lies in the perfection of the purpose that it is assigned. Because man is principally a rational being, the perfection of this quality is its final accomplishment. ${ }^{8}$ Plotinus (c.

${ }^{2}$ John Scott and Oxford University Press, A Dictionary of Sociology, 4th ed. (Oxford: Oxford University Press, 2014), 673-74.

${ }^{3}$ Rom Harre, Social Being 2e, 2 edition (Oxford, UK; Cambridge, Mass., USA: John Wiley \& Sons, 1993), 4.

${ }^{4}$ H. J. Kleine Störig, Weltgeschichte Der Philosophie (Malè Déjiny Filozofie), Cžech Translation. Zvon. (Praha: České katolické nakladatelství, 1991), 37.

5törig, 43.

${ }^{6}$ Störig, 103.

${ }^{7}$ Störig, 122-23.

${ }^{8}$ Störig, 136-37. 
204-270 AD, Lycopolis, Egypt) believes in the divine origin of the human soul that he describes as the emanation of the 'highest being' (God). For Plotinus, the eternal, the highest being (the One or the First, God), tough overflows, and its effusive fullness generates everything. As the sun that radiates warmth without losing anything from its substance, likewise, the highest being radiates almost as its reflection and shadows everything that exists. Plotinus considers this emanation gradually and that there is a hierarchy of different spheres of existence, depending on their proximity to God. The divine soul is not God himself, who stands beyond it. Plotinus also talks about 'the world's soul that is closest to god and 'individual' souls. Individual souls are situated between the world's soul and the material world, which is considered the least perfect and the most distant from God. Plotinus believes the whole world spirit is present in every individual soul, and that every individual soul carries the complete universality. For Plotinus, because of the divine origin of the human soul, the highest objective of man and his happiness lies in his return and its unification with God, from whom it originates. ${ }^{9}$

One of the most influential Christian philosophers of the middle ages, Thomas Aquinas (1225-1274 AD, Roccasecca, Italy), in line with Aristotle, defines the soul as the determining principle that creates the foundation of all phenomena of life. For man, it means "the principle of the thought activity, a rational soul, and the essential form of the human body." Thomas Aquinas believes the human soul is immaterial and an essence independent of the material; hence, indestructible and immortal. Because the soul is independent of the body, it cannot be destroyed with the body. Moreover, he thinks that the human desire for immortality is not a deception, but a testimony to the immortality of the soul. Like Aristotle, Thomas Aquinas distinguishes vegetative, animal, and rational parts of the soul. ${ }^{10}$ Johannes Eckhart (1260 - 1327 AD, Köln, Germany), the prominent German mystic of the Middle Ages, is of the view that the human soul is created in the image of God; he says as God's trinity, so is the human soul that consists of three spiritual powers; knowledge, vexation, and volition (desire), that Eckhart links with three central Christian values such as faith, love, and hope. However, as there is one God above the God's trinity, the soul stands as a divine "flicker" above these three spiritual powers - "So pure, noble and chivalrous with nothing created inside it but only God with its pure divine nature." "The flicker of the soul is the light of divine equity, that always returns to God." For a man to unite with God, in Eckhart's opinion, he should avoid sins that keep him away from God; reach the state of internal peace, and finally to come to "exemption"; parting from all earthy objects and consequently from oneself, and giving up one's self volition and enter to the will of God. If the soul achieves such a state and gets rid of all that separates him from God, it will become God himself. The soul is such a state that enters eternity. ${ }^{11}$

${ }^{9}$ Störig, 151.

${ }^{10}$ Störig, 190-91.

${ }^{11}$ Störig, 200.

Khazanah, Vol. 18 (1), 2020 
Similarly, Jakob Böhme (1575-1624 AD, Görlitz, Germany), an influential philosopher of the renaissance and baroque age, believes in the divine nature of the human soul and its reunion with God as its highest aim and the only salvation. Nonetheless, he believes, until covetousness and disunity shackles man, it "would not release himself from them, unless he would not get rid of his greed, quietened his desires, and become the instrument of God he would not reach the deepest foundation of unity." 12

Furthermore, the baroque epoch German philosopher Gottfried Wilhelm Leibniz (1646 - 1716 AD, Leipzig) uses the term "monad" for the soul. As described by Leibniz, the lowest monads are in dream-like or daze-state and have only dark and unconscienced ideas. Higher monads, such as the human soul, have a conscience. The highest monad - god, has an infinite conscience and is omniscient. In Leibniz's opinion, monads are individual entities, and there are no two similar monads. Each monad has its unique place, each reflects a unique universe of its own, and each has the potential to reflect the whole universe. ${ }^{13}$

As far as Islamic philosophy and Sufi mysticism are concerned, selfknowledge has been one of the most important topics of their deliberation. Sufi mystics and Muslim philosophers emphasize that the purpose of man's life is to discover the unique "tree" of knowledge and to consume its fruits, which will bring man "immortality." 14

They concur that there is no higher knowledge than the knowledge of self, as "He who knows himself knows God."15 In line with the Sufi tradition, God says, "I was a hidden treasure, and I desired to be known, so I created the creation in order that I may be known." ${ }^{\text {16 }}$ Every object reflects one or more of the divine attributions, however man, as the microcosm, reflects them all. Man, is the eye of the world, whereby God sees His own works" ${ }^{17}$

${ }^{12}$ Störig, 225.

${ }^{13}$ Störig, 292.

${ }^{14}$ Ghomshei Elahi Hossein, In the Realm of 365 Poems and Discourses from Rumi (Tehran: Sokhan Publishers, 2012), 199-201. See also Jallaluddin Mohammad Rumi-Balkhí, Masnawi e Mánawi, Based on Qoniya MSS, Dated 677 H, Edited by Kázem Bargnaysi, vol. I \& II (Tehran: Fekr e Roz, 2010), 434.

${ }^{15}$ Sanai-e- Qaznavi Abolmajd Majdoud ibne Adam, Hadiqat-Ol-Haqiqat va Shariat-Ol-Tariqat. 8th Edition (Tehran: University of Tehran Press, 2015), 373. See also Balkhi Jalaluddin Mohamad, Maulana Fibe Ma Fihe; Moqhadema, Tashih Wa Taliqhat, Doctor Babman Nehzat (Tehran: Entesharat e Sokhan, 2016), 9.; Rumi-Balkhí, Masnawi e Ma'nawí, Based on Qoniya MSS, Dated 677 H, Edited by Kázem Bargnaysi, I \& II: 980. See also Ghazali Mohammad bin Mohammad, Gozidah-e Kimyaye Sa'adat, 4th Edition (Tehran: Mosese Entesharat e Qhadyani, 2013), 50. See also Nizami Aruzi Samarkandi and Ahmad bin Umar bin Ali, Chahár Maqbála (Four Discourses), Originally Written in circa 550 Hijri; Edited by Qazwini M (Tehran: Entesharat e Armaghan, 1905), 16.

${ }^{16}$ Abdurrahman bin Ahmad Jami, Haft Awrang (Tehran: Entesharat e Mahtab, 2003), 69. See alsoRumi-Balkhí, Masnawi e Ma'nawi, Based on Qoniya MSS, Dated 677 H, Edited by Kázem Bargnaysi, I \& II:830.

${ }^{17}$ Jalaluddin Rumi, Selected Poems from the Divan-e-Shams-e Tabrizi Edited and Translated by Reynold Alleyne Nicholson (Maryland: IBEX Publishers Bethesda, 2001), 208. 
In terms of Farsi-Dari literature, the Arabic word "Nafs" نفس is used for the expression of the ego, self and identity. Nafs or soul is defined as a power that keeps a body alive and is also defined as a substance that is not physical and is rather one's identity or the truth of a thing or a person. The word 'nafs' can also be translated as a person, a body, corpus, intention, blood as well as the male reproductive organ. ${ }^{18}$ Likewise, 'nafs' is used as a synonym for the spirit or 'ruh' حوح. Ghazali 19 distinguishes 'nafs' from the 'rub' believing it is impossible for ordinary people to understand the truth about the 'rub', referring to Quran 'They question you concerning the Spirit. Say, The Spirit is of the command of my Lord, and you have not been given of the knowledge except a few'. ${ }^{20}$ Furthermore, The Quran refers to three forms of nafs; the carnal nafs or an-nafsul-amara, 'Yet I do not absolve my [own carnal] soul, for the [carnal] soul indeed prompts [men] to evil, except inasmuch as my Lord has mercy. Indeed, my Lord is all-

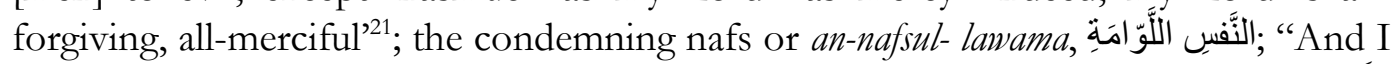
swear by the self-blaming soul! المُطحَبَنَّنَةُ 'O soul at peace! Return to your Lord, pleased, pleasing! ${ }^{23}$. In fact, the theme of the 'nafs' or self is the principal subject of debate of the philosophers like Razi, Farabi and Avicenna as well as the three greatest Sufi mystics, such as Sanai Ghaznawi, Attar Nishapuri and Jalaluddin Balkhi - Rumi.

It is important to stress that especially in philosophical literature, the word intellect, aqbl عقل is used as the synonymous for the word soul, or nafs.

\section{Methods and Objectives}

This is a literature review of available works originally written in Farsi-Dari or Persian literature, and Arabic literature translated either into English, and Farsi-Dari, but also into other languages such as Czech or Slovak that the author is familiar with. The author has used originals works of Sufi mystics as Ghazali's Kimya ye Sa'ädat (The Alchemy of Happiness), Sana'i Ghaznawi's The Hadiqhatul Haqbigha wa Shari'atul Tariqha (The Garden of Truth and The Right Path); Attar's Ellähi Nämah and Mantequl-Tayr (The Conference of Birds), and Rumi's Masnawi Ma'nawi, Diwan e Shams $e$ Tabrezi and Fibe Má Fìh. The author has mostly used translation of philosophical works from Al-Kindî, Razi, Farabi and Avicenna. Nonetheless, the author has also had access to the Persian translation of Avicenna's philosophical works.

This paper will examine the concept of the self-knowledge (" $n a f s$ ) from the perspective of early Muslim philosophers such as Razi, Farabi and Avicenna, as well as the standpoints of Sufi mystics like Sanai of Ghazna, Attar of Nishapur, and Rumi of Balkh. The Aristotelian philosophy of soul has significantly influenced the early

\footnotetext{
18“Dehkhoda Version 2.0 APK by Farzad Rashvand," 2016.

${ }^{19}$ Mohammad bin Mohammad, Gozidah-e Kimyaye Sa'adat, 53.

${ }^{20}$ Quran, 17: 85, www.al-quran.info.

${ }^{21}$ Quran, 12: 53, www.al-quran.info.

${ }^{22}$ Quran, 75: 2, www.al-quran.info."Quran.”

${ }^{23}$ Quran, 89: 27-28, www.al-quran.info.
}

Khazanah, Vol. 18 (1), 2020 
Islamic philosophy of 'nafs'; nevertheless, the Muslim philosophers themselves had a significant influence on the further development of philosophy in Europe and around the world. Sufi mystics, been hugely prominent in Central Asia, the Middle East, and Muslim countries in general. What is distinctive of Islamic Sufi mysticism is that they guide to universal tolerance, saying all mankind in different ways search and worship the same God, and despite the difference of cults, there exists the one and only highest truth. Works of both great Muslim philosophers and Sufi mystics are known only to a limited number of researchers and academics. However, they are not as recognised and represented to the wider public as they deserve to be. In the following, the important questions are (1) what the nafs (self) is; (2) where we come from; (3) what the purpose of our life is, and (4) what true happiness and misery entail.

\section{Results \& Discussion}

\section{Who are we and where do we come from?}

Early Muslim philosophers such as Al-Kindî (801-873, Kufa, Iraq), in his Risálah fil-Aql (Statement on the Soul), Zakarya al-Razî (854-925, Ray, Iran) in The Opera Philosophica; Abu Nasr al-Fârâbî (c. 870-950, Faryab, أغر اض ارسطوطاليس في كتاب ما Afghanistan) in The Aims of Aristotle's Metaphysics بعدالطبيعه Aghrāz Arastutāles Fil-Kitābe Mā Ba'd al-Tabīa) and Abû Alî Hussein ibn Sînâ or Avicenna (980-1037) who came from a noble family from Balkh, Afghanistan in الثنا Ash-Shiffá (The Healing) and كتاب النجات the Kitáb e Nejât (The Deliverance), emphasise the immortal nature of the soul. They highlight its origins as a tripartite (vegetative, animal and rational) unified substance created by God, which returns through various stages to be in close proximity to its Creator, having lived a life controlled by its rational faculty. ${ }^{24}$ Farabi defines the soul as "that by which the living substance - I mean that which admits of life - is realized as substance, serving the triple function of being a formal, organized and final cause. For human beings, the intellect (soul) assumes the mantle of substance, it being "a principle underlying the essence of man," both as an agent and final cause. In line with Aristotle, for Farabi, it is the rational faculty of the soul, which is unique to human beings and distinguishes them from plants and animals. It is also the only part of the soul to survive the death of the body. ${ }^{25}$ Both Razi and Avicenna, following Hellenistic tradition, locate the rational soul in the brain; the animal soul in the heart, and the vegetative soul in the liver. ${ }^{26}$ Nevertheless, in contrary to Razi and Avicenna, Farabi considers the rational soul as having no physical organ to sustain it. ${ }^{27}$ Avicenna, except for the terrestrial soul, or nafs ardi نفس ارضي (vegetative, animal and

${ }^{24}$ Ivry Alfred, Arabic and Islamic Psychology and Philosophy of Mind (The Stanford Encyclopedia of Philosophy (Summer 2012 Edition), Edward N, 2019), 2.

${ }^{25}$ Adamson Peter and Taylor Richard C., Black Deborah. Psychology: Soul and Intellect in The Cambridge Companion to Arabic Philosophy. (Cambridge: Cambridge University Press, 2005), 184.

${ }^{26}$ Alfred, Arabic and Islamic Psychology and Philosopby of Mind, 3.

${ }^{27}$ Alfred, 5. 
human soul), also talks of the celestial soul or nafs samânir نفس سماوي, considering that all planets and the universe have a soul. ${ }^{28}$ For Avicenna, the vegetative soul consists

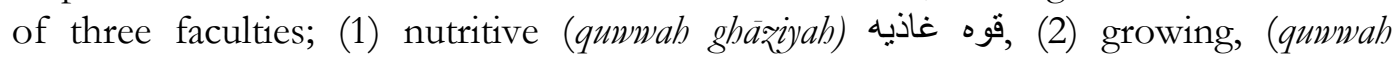
nāmiyah) قوه ناميه and (3) reproductive قوه مولده (quwwah mowalledab). Avicenna

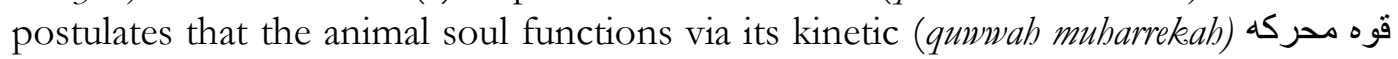
and cognitive (quwwah mudarrekah) قوه مدركه faculties. The kinetic factuality of the animal soul consists of (1) satisfying function or aوه شهوّه quwwah shabwat (lust and libido) triggering movements towards pleasurable behaviours; and (2) repulsing or قوه غضب (quwwah ghadab) or anger functions, triggering towards repellent behaviours. The cognitive faculty of the animal soul is conducted by its five external sensory faculties (visual, auditory, gustatory, olfactory and tactile senses) and by five internal faculties such as قوه بنطاسيا quwwah bantasia (the common sense); قوه مصوره quwwah

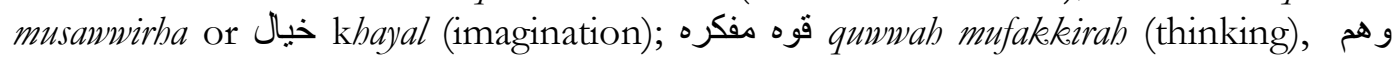
wahm (estimation); and قوه ذكر qumwah dekr or hafezah حفره or memory. defines the celestial or divine soul نفس سماوي "nafs sammawi" as unequivocally independent, self-conscious, substantial and immortal that is generated by God and emanated upon the body, having a natural inclination nira (نز $(ن)$ ), for the body that has come into being. Moreover, the soul is individuated by the specific nature of its designated body, which it strives to bring to moral and intellectual perfection. ${ }^{30}$

As far as Sufi mystics are concerned, thier perception of the nafs is parallel to Muslim philosophers; yet, they use a somewhat distinctive language. The influential

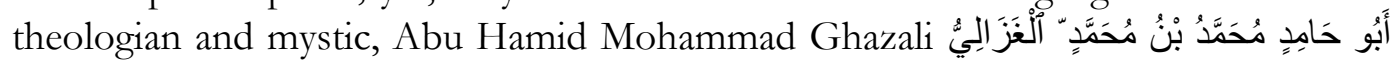
(born 940 in Tus, Iran) in his colossal Kimya ye Sa'ádat كيمياى سعادت (The Alchemy of Happiness) expresses an opinion that "nothing is closer to man than himself" ${ }^{31}$. For Ghazali a human being is composed of an outward shape, zäher, ظاهر or the body, tan nafs that is the truth of a man and everything else is its servant, and its army. Ghazali believes man's soul is tripartite, consisting of (1) "animal" حيواني (baywáni), preoccupied with eating, sleeping and fighting; (2) "demonic" or شيطاني (shaytáni), busy in stirring up mischiefs and deceit; and (3) an "angelic" ملكي (malaki) spirit, contemplating to the beauty of God, entirely free from animal and demonic qualities. ${ }^{32}$

On the other hand, Abolmajd Majdud bin Adam Sanai of Ghazna مجود المجد (1080-1131, Ghazna, Afghanistan) in The Hadiqhatu'l Haqhiqhah wa Shari'atul Tariqha حديقه الحقيقه و شريعه الطريقانه The Garden of Truth and The Right Path)

${ }^{28}$ Ibn Sina, Fin Nafs-al Ardiya Was-Samawiya, Bakhshayeshi J.F., vol. 1 (Tehran: Entesharat e Ayat Ashraqh, 2012), 49-50.

${ }^{29}$ Ibn Sina, Taheri, S.M. A Translation of Seventeen Essays from The Collected Essays, Translation (Tehran: Entesharat e Ayat Ashraqh, 2009), 174-84 and 3030-310.

${ }^{30}$ Alfred, Arabic and Islamic Psychology and Philosophy of Mind, 4.

${ }^{31}$ Mohammad bin Mohammad, Gozidah-e Kimyaye Sa'adat, 50-59.

${ }^{32}$ Mohammad bin Mohammad, 50-59.

Khazanah, Vol. 18 (1), 2020 
posits it was the "Inventor" ( مبدا mabda') who created the existence (wujud) and the tri-dimensional nature (طبيعت tabi'at) from the combination of the matter (مايه máa) and the form (صورن surat) as well as the time (زمان zaman) and space (در dabr). Afterward from the marriage of "seven celestial fathers" (seven planets: Moon; Mercury; Venus; Sun; Mars; Jupiter and Saturn) and four "terrestrial mothers" (water, wind, earth and fire) he nurtured "three children" (plants, inanimate objects and animals). When hundreds of thousands of worlds were created, he then revealed from the occult veil that which is distinctive of all creations, the essence or soul ( جوهر jawhar) of man. Sanai describes four souls; (1) the "growing", vegetative

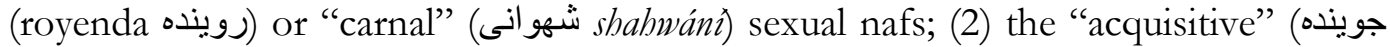
joyenda) hunter or animal (حيوانى haywáni) nafs; (3) the "talking" (كوينده goyenda), dialectic or human انسانى insáni) nafs, and (4) the "purifying" (شوينده shoyenda) or divine (ربانى rabbáni) nafs. ${ }^{33}$ It appears that Sana'i expresses the doctrine of "Nafs “jesmaniyat-ul-huduth wa ruhaniyat-ul baqha” نفس جسمانية الحدوث روحانية البقا expressing an opinion that the human soul is being created and evolved from matter; "after mineral and nature in mankind; know this that the invitation of reason, a'qbl (عقل intellect) was later. If the faith (نفس spirit) follows animal and vegetable, do not think it is strange. It is the same as when a child-girl first looks after a baby doll, and later (when a mother) cares for a child." 34 Similar opinion was expressed 100 years later by Sanai's compatriot, Rumi; "First you were mineral, later you turned to plant. Then you became an animal; how could this be a secret to you? Afterwards you were made man, with knowledge, reason, and faith; Behold the body, which is a portion of the dust-pit, how perfect it has grown; When you have travelled on from man, you will undoubtedly become an angel; After that you are done with this earth: your

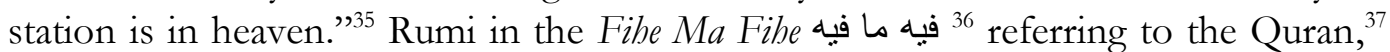
contends that "you will surely experience state after state; So, what is [the matter] with them [that] they do not believe" explains the journey of humankind as "being created from nihility to mineral, from mineral to plant; from plant to animal; from animal to human; from human to angel" 38 or "you were dust and became soul, you

${ }^{33}$ Sanai-e- Qaznavi Abolmajd Majdoud ibne Adam, Hadiqat-Ol-Haqiqat va Shariat-Ol-Tariqat. 8th Edition (Tehran: University of Tehran Press, 2015), 27-28; 382-383.

${ }^{34}$ Qaznavi Abolmajd Majdoud ibne Adam, 385.

${ }^{35}$ Hossein, In the Realm of 365 Poems and Discourses from Rumi, 93; Rumi, Selected Poems from the Divan-e-Shams-e Tabrizi Edited and Translated by Reynold Alleyne Nicholson, 48-49.

${ }^{36}$ Jalaluddin Mohamad, Maulana Fihe Ma Fibe; Moqbadema, Tashib Wa Taliqhat, Doctor Babman Nehzat, 18.

${ }^{37}$ Quran, 84: 19-20, www.al-quran.info.

${ }^{38}$ Jalaluddin Mohamad, Maulana Fihe Ma Fihe; Moqhadema, Tashib Wa Taliqhat, Doctor Babman Nehzat, 17.; Jallaluddin Mohammad Rumi-Balkhí, Masnawi e Ma'nawi, Based on Qoniya MSS, Dated 677 H, Edited by Kázem Bargnaysi, vol. I \& II (Tehran: Fekr e Roz, 2010), 861-62; Rumi, Selected Poems from the Divan-e-Shams-e Tabrizi Edited and Translated by Reynold Alleyne Nicholson, 46-48. 
were ignorant and became wise; who he has led you so far will lead you further' ${ }^{39}$; or 'make a journey out of self into self, $\mathrm{O}$ master; for such a journey earth became a مuarry of gold' ${ }^{40}$. This idea was 500 years later expressed by Mulla Sadra ' (1571-1640, Shiraz, Iran) who, based on his theory of "al-barakart al-jawhariyyah" or "substantial motion," believes that human soul is not primary independent substance (as defined by Al-Kindî, Rázi, Fârâbî and Avicenna), however, it originates from the matter. The matter, based on its own substantial motion, gradually evolves and transforms from the material to immaterial. ${ }^{41}$ Mulla Sadra, referrers to Quran as a testimony of his views; "And certainly did We create man from an extract of clay" "42; "And Allah created you from dust, then from a spermdrop; then He made you mates"43, or "And Allah has caused you to grow from the earth a [progressive] growth." 44

فريد الدين ابو حامد بن ابوبكر Equally, Fariddudin Abu Hámid Mohammad Attar عطار - 1221, Nishapur, Iran) believes the substance of mankind is divine, and that the mankind is the purpose of the creation; "the prince and the deputy of God on earth". However, because of man's fixation to physical and earthy desires he is unable to reach his potential; 'Isn't your substance the subject of Angels' worship; isn't the crown of vicariate on your head? You are the first and the last king; but held in deception of binary. You see one (as) two; whether one or two, or hundred, all is you." 45

As his predecessors Sanai and Attar, the great mystic Jalaluddin Mohammad Balkhi - Rumi (1207, Balkh, Afghanistan - 1273) describes three kinds of creations: (1) angels that are entirely of knowledge and wisdom; (2) animals, which are empty of knowledge and are unaware of honour and calamity; and (3) the mankind who is half angel and half animal, both in battle as to which one half will win. If wisdom (angelic soul) prevails, man will be better than angels. Nevertheless, if his animal half (soul) prevails, mankind will be lower than animals. ${ }^{46}$ Correspondingly to Ghazali, Rumi interprets the physical body as the instrument of the soul. This is analogous to the Aristotelian interpretation of the body as the 'organ' of the soul. ${ }^{47}$ Rumi compares the association of the soul to a body to a

\footnotetext{
${ }^{39}$ Rumi, Selected Poems from the Divan-e-Shams-e Tabrizi Edited and Translated by Reynold Alleyne Nicholson, 142-43.

${ }^{40}$ Rumi, 111.

${ }^{41}$ Gorgin and Esfehani, "Evolution of the Humankind Based on Theory of 'Soul Being Generated from the Matter and Perpetuating as Spirit," Journal of Religious Thought of Shiraz University, Ser. 50, (Spring 2014), 14, no. 1 (n.d.): 23-38.

${ }^{42}$ Quran, 23: 12, www.al-quran.info.

${ }^{43}$ Quran, 35: 11, www.al-quran.info.

${ }^{44}$ Quran, 71: 17, www.al-quran.info.

${ }^{45}$ F.M Attar, Illahee Namah Kadkani M.R.S (Tehran: Entesharat e Sokhan, 2006), 29-35.

${ }^{46}$ Rumi-Balkhí, Masnawi e Ma'nawi, Based on Qoniya MSS, Dated 677 H. Edited by Kázem Bargnaysi, I \& II:760-61.; Hossein, In the Realm of 365 Poems and Discourses from Rumi, 57

${ }^{47}$ H. J. Kleine Störig, Weltgeschichte Der Philosopbie (Malé Déjiny Filozofie), Czech Translation, Čtvrté Vydání (Praha: Zvon. Ceské katolické nakladatelství, 1995), 136-37.
}

Khazanah, Vol. 18 (1), 2020 
relationship between a horse and a rider; inferring "you are the rider; your body is your horse and the world is its manger; the food of the horse is different from food of the rider (soul). You sat on your horse (of body) stuck in the corridor of stable, far away from the kings and sultans of the eternal world." 48 Rumi suggests "behold animals keeping their heads to earth; you are a man, turn your head atop" ${ }^{49}$. Rumi, like his predecessors, Attar and Sanái considers the human soul is like 'Messiah in the cradle of the body"; or "child, Jesus sat in an ass for humility's sake; how else should the zephyr ride on the back of an ass. ${ }^{50}$

Furthermore, Rumi understands the physical body as a prison where the spirit is captive, saying "I am sure my soul is from the heavens, surely I will travel back there. I am a bird of the Angeles garden, for a few days they made me a cage." 51 Similar opinion is expressed by Nasser Khosraw (born in 1004 AD, in Qhubadyan near Balkh, Afghanistan) who equates the physical body to a "prison" that man would never make handsome "even if it is dressed in silk clothes" and "soul's transitory home, only a handful of soil, man therefore should not cultivate it." 52 This connotation of the physical body to cage appears to be originating from Plato who refers to the body as the grave ('soma séma') of the soul that does not allow man to reach the extra sensual world. ${ }^{53}$ In Rumi's opinion, people should remember their "divine" origin and should not sell their soul for a handful of dust; "do you know where you have come from? From the midst of all glorious sanctuary, do you not remember at all those happy spiritual stages? Those things have become forgotten by you, so necessarily you are bewildered and distraught. You sell your soul for a handful of dust; what kind of bargain sale is this? Give back the dust and know your own value; you are not a slave, you are a king, an emperor. For your sake, there came out of haven the fair-faced ones, the sweetly hidden." ${ }^{54}$ A somewhat similar view is expressed by the famous Greek philosopher Plotinus; 'What has caused the souls, which yet belong to the other world, to have forgotten their Creator and not recognise themselves and Him? The beginning of their evil was audacity, descendence to creation, the first otherness, and the will to be themselves. Because they enjoyed their freedom when they entered the phenomenon, they excessively enjoyed the ability to move freely, and because they were moving to the opposite

\footnotetext{
${ }^{48}$ Jalaluddin Mohamad, Maulana Fihe Ma Fibe; Moqbadema, Tashib Wa Taliqhat, Doctor Bahman Nehzat, 14.

${ }^{49}$ Ghazalyat-e Shams-e Tabriz, Selected Ghazals by Jalál-al-Din Mohammad of Balkh (Rumi) A.H. 604-772/ AD 1207-1273. Edited by Kadkaní M.R.S, vol. II (Tehran: Sokhan Publishers, 1999), 965.

${ }^{50}$ Rumi, Selected Poems from the Divan-e-Shams-e Tabrizi Edited and Translated by Reynold Alleyne Nicholson, 17; 209.

${ }^{51}$ Hossein, In the Realm of 365 Poems and Discourses from Rumi, 518-20.

${ }^{52} \mathrm{~N}$ Khosraw, Gozidah- e Diwan-e Nasser Khosraw, 1st ed. (Tehran: Mosese Entesharat e Qhadyani, 1998), 151.

${ }^{53}$ Störig, Weltgeschichte Der Philosophie (Malé Déjiny Filozofie), 122-23.

${ }^{54}$ Molawi Jalaluddin Rumi, Silent Words, a Selection of Poetry and Prose, Translated by R.A. Nicholson

\& A.J. Arbery (Tehran: Hermes Publishers in collaboration with The Centre for Dialogue among Civilisation, 2004), 950-51.
} 
path, they have moved too far; hence they lost the cognition that they are from there; like children that are taken away early from their fathers and for a long time are brought up far away from them; they do not know who they are nor who their father is. Because they have not seen neither Him nor themselves; they did not value themselves because of the lack of knowledge of their origin; they, however, valued other things much higher; they admired them more than themselves; they marvelled everything else and were proud of them (because of possessing them) and became dependent on them." ${ }^{45}$ In Rumi's opinion, the physical body is an 'immense deceit" as the true essence of the human being consists of the soul that is eternal; "before there was the caliche of wine and grape in this world; our soul was drunk from the eternal wine. ${ }^{, 55}$ In the view of Jalaluddin Balkhi - Rumi, the true substance of mankind is his 'nafs' (soul), stressing "O brother you are the very idea, the rest is just bones and roots." ${ }^{.56}$ This exact idea was expressed in the 16th century by the Spanish philosopher Gomez Pereira. "Nosco me aliquid noscere, \& quidquid noscit, est, ergo ego sum." meaning "I know that I know something, anyone who knows exists, then I exist" ${ }^{\prime 57}$ and a century later by Descartes, known as Descartes' dualism - embracing the idea that mind and body are distinct but closely joined ${ }^{58}$. Descartes gives priority to the mind and argues that the mind could exist without the body. However, the body could not exist without the mind..$^{59}$

\section{What the purpose of our life is, and what do real happiness and misery consist of?}

Muslim philosophers regard the pursuit of knowledge as a divine command. As the greater the knowledge accumulated, the closer it brings one to ultimate happiness. Razi supposes that the human soul needs divine intervention to liberate itself from the seductive and defiling matter of the world. In Spiritual Medicine ( $\mathrm{Al}$ Tibb al_rubáni الطب الروحاني), Razi expresses a belief in the transmigration of souls; stating the rational soul of an individual needs to liberate itself from the seductive and defiling matter of the world lest it be reincarnated in another, not necessarily human, body. ${ }^{60}$ The idea of transmigration of souls has its roots in the ancient faith of the Upanishads, ${ }^{61}$ but it has also been expressed by the Greek philosopher Pythagoras, who lived between years 580 and 500 BC. In Pythagoras's view, after

${ }^{55}$ Rumi, Jalaluddin. Selected Poems from the Divan-e-Shams-e Tabrizi Edited and translated by Reynold Alleyne Nicholson. Maryland: IBEX Publishers Bethesda, (2001), 247-8.

${ }^{56}$ Balkhi, Jalaluddin Mohamad, Maulana Fihe Ma Fihe; Moqhadema, Tashih wa Taliqhat, Doctor Bahman Nehzat., Tehran: Entesharat e Sokhan, (2016), 159.

${ }^{57}$ José Manuel García-Valverde and Peter Maxwell-Stuart, Gómez Pereira's Antoniana Margarita (2 Vols): A Work on Natural Philosophy, Medicine and Theology (Brill, 2019), 277. Santos López, Modesto (1986), 277.

${ }^{58}$ David Cunning, The Cambridge Companion to Descartes' Meditations (Cambridge: University Press, 2014), 277.

${ }^{59}$ Georges Dicker, Descartes: An Analytic and Historical Introduction (OUP, 2013), 301.

${ }^{60}$ Alfred, Arabic and Islamic Psychology and Philosophy of Mind, 3.

${ }^{61}$ Störig, Weltgeschichte Der Philosophie (Malé Déjiny Filozofie), 39.

Khazanah, Vol. 18 (1), 2020 
death, human souls go through a long process of purification and reincarnation (transmigration), including reincarnating as animals. Analogously to Upanishads' doctrine, Pythagoras also believed one could achieve redemption only if they refrain from physical desire and live a strict ascetic way of life. ${ }^{62}$ Contrary to Razi, Farabi does not believe in the transmigration of souls. Farabi is of the opinion that beyond the individual intellect (soul) there lies a universal Agent Intellect, which he calls Active Intellect, al-'aql al-fa'all (العقل الفعال). The Agent Intellect is the formal principle of the soul that is the ultimate mediator and final cause of the individual intellect. It both facilitates the individual intellect's operations and, serving as an example of perfect being, drawing it back towards itself through acts of intellection, ta'aqhol (تعقل). The more the individual's intellect (his soul) is absorbed in theoretical activity, the greater its accumulation of scientific knowledge; each step bringing it closer to that totality of knowledge and essential being encapsulated (فن in the Agent Intellect. For Fárábi as stated in Árā' abl al-Madinatul-Fadela wa Madātehāa آرا اهل المدينة الفاضلة -The Opinions of the People of the Perfect City- the formation of a substantial amount of knowledge is that which forms and enriches us, creating a substance that in its immateriality resembles the Creator. This represents "ultimate happiness" - al-sa'âdah al-quswâ السعاده القصوي and an afterlife - al-hayâh al-âkhîrah (الحياه الآخره) Statement on the Soul (Risálah fíl-Aql رساله في العقلاه) considers the human soul's desire to resemble his Creator whose proximity is his happiness; hence a superior person, or fâdil (فاضل) who avoids physical desires and pursues wisdom, or hikmah (حكمد), justice, goodness, and truth resemble the Creator. This resemblance, however, relates to God's activities, not to His essence. ${ }^{64}$ Notwithstanding, for Avicenna, the materialisation of knowledge alone is not sufficient for the ultimate salvation of the soul. Avicenna postulates that depending on the amount of knowledge the individual accumulates, but also on the life the person lives (with its virtues or vices), the immortal soul experiences continuous pleasure or pain. Avicenna describes four categories of souls after the separation from the physical body; (1) Firstly, those souls that acquire knowledge, ullum and ma'aref (علوم و معارف) and are free from physical desires will be in absolute happiness, or sa'âdah mutlaq (سعادة مطلق) (2) Secondly, those souls that have obtained knowledge, but because they are (still) contaminated with sins will be suffering as long as the pollution (of their souls) lasts. Nonetheless, with the lapse of time and as the contamination fades away; those souls will reach ultimate happiness; (3) thirdly, souls that have not attained any knowledge, despite being innocent and sinless, will be experiencing eternal suffering as they were ignorant of the righteous and have not tried for perfection; and (4) finally, souls of those who are innocent, like children, or during their lives followed the righteous paths of prophets but did not (knowingly) pursue wisdom or have not been guided;

\footnotetext{
${ }^{62}$ Störig, 99.

${ }^{63}$ Alfred, Arabic and Islamic Psychology and Philosophy of Mind, 7.

${ }^{64}$ Alfred, 2.
} 
these two groups will experience neither absolute happiness, sa'âdah mutlaq, سعادة مطلق nor absolute suffering, shaqhāwah mutlaqh, شقاو مطلق

In accordance with Muslim philosophers, Ghazali believes that the soul in its essence is 'thirsty' for redemption, sa'âdah, which he defines as 'the knowledge of God and the observation of His beauty'. Ghazali supposes the soul has come to this world as a traveller and will return to its native land near God. It is here that this traveller soul, by using his bodily senses, acquires knowledge of the works of God, and through them, of God Himself, the sight of who will constitute his future beatitude. "It is for the acquirement of this knowledge that the spirit of man has descended into this world of water and clay." ${ }^{66}$ Ghazali considers God created man in his image, hence if man avoids damnification moblekeat مهلكات (such as lust, hatred, greed, jealousy, animosity, stinginess, pride, etc.), and pursues redemption, monajeyät منجيات (such as repent, patience, gratitude, fear, hope, ascetics, sincerity, reliance, remembering death, etc.) he will achieve the ultimate happiness. ${ }^{67}$ Correspondingly, Sanái believes man is the intention of creation and the purpose of existence; he is divinely nurtured and the sight of Creation. Man, has been given obligation, intellect and insight. Heaven, earth and time are all for him. ${ }^{68}$ In Sanai's view, man, therefore, if he does not want his eternal garment to be burnt; he shall set fire into the garment of his body. ${ }^{69}$ Sana'i understands that the purpose of a human's life is attaining as much knowledge as possible, because it is knowledge that will take man to the doorstep of the Creator: "When the substance of Adam's offspring is separated from the attire of water and earth, when the five spies of senses (five sensory organs) are jailed in the prison of nihility; and when his four physical nails (water, wind, fire and air) are sent back to the four mines; his dust will be sent to dust. However, at the day of questions and answers, his soul will be rewarded according to the size of their knowledge, ${ }^{70}$ and it is the acquired knowledge that will guide man to happiness. However, if ignorant, a person will not reach the other world, will be degraded, and turned into darkness and misery. ${ }^{71}$

\section{Conclusion}

The understanding of the self is of paramount significance because as individuals we wonder who we are; where we come from; what the purpose of our life is, and what true happiness and misery entail. Mankind is composed of an external form or body, and an internal entity, which is one's true substance, self, mind or soul. Both, Sufi mystics and Muslim philosophers believe that mankind is a union of mind and body; nevertheless, they consider the physical body to be a

${ }^{65}$ Sina, Taberi, S.M. A Translation of Seventeen Essays from The Collected Essays, 602-4.

${ }^{66}$ Mohammad bin Mohammad, Gozidah-e Kimyaye Sa'adat, 69-70.

${ }^{67}$ Mohammad bin Mohammad, 30-35.

${ }^{68}$ Qaznavi Abolmajd Majdoud ibne Adam, Hadiqat-Ol-Haqiqat va Shariat-Ol-Tariqat. 8th Edition, 374-75.

${ }^{69}$ Qaznavi Abolmajd Majdoud ibne Adam, 345.

${ }^{70}$ Qaznavi Abolmajd Majdoud ibne Adam, 31-32.

${ }^{71}$ Qaznavi Abolmajd Majdoud ibne Adam, 315.

Khazanah, Vol. 18 (1), 2020 
deception, as the true essence of human consists of his soul, which is eternal and divine. They emphasize the immortal nature of the soul, created by God that returns through various stages to be in closer proximity of its Creator. They concur "although man is not primordial, he is eternal; while his corpus is terrestrial, his soul is divine; and although his essence is mixed with animal and voracious attributes; if he gets rid of his maleficence, man will reach proximity to God, which represents ultimate happiness.

As far as Muslim philosophers and Sufi mystics are concerned, their perspective emphasizes what has been accentuated throughout history by the philosophies of ancient India and Greece as well as that of Medieval European philosophers. Whether the essence of mankind is called 'átman' as expressed by ancient Upanishad faith or 'jiva' as described by the Mahavira religion, or 'the primal fire' as outlined by Heraclitus, or 'monad' as called by Leibniz, or 'nafs' as termed by Muslim philosophers or Sufi mystics; it is all the same; the most inner core of human beings - its soul. All philosophers, regardless of their religious beliefs, agree that mankind is created from the same essence that is divine, immortal and ultimately desires to return to its creator.

\section{Rererence}

Alfred, Ivry. Arabic and Islamic Psychology and Philosopby of Mind. The Stanford Encyclopedia of Philosophy (Summer 2012 Edition), Edward N ..., 2019.

Aruzi Samarkandi, Nizami, and Ahmad bin Umar bin Ali. Chahár Maqbála (Four Discourses), Originally Written in circa 550 Hijri; Edited by Qazwini M. Tehran: Entesharat e Armaghan, 1905.

Attar, F.M. Illahee Namah Kadkaní M.R.S. Tehran: Entesharat e Sokhan, 2006.

Colman, Andrew M. A Dictionary of Psychology. Fourth Edition. Oxford: Oxford University Press, 2015.

Cunning, David. The Cambridge Companion to Descartes' Meditations. Cambridge: University Press, 2014.

“Dehkhoda Version 2.0 APK by Farzad Rashvand," 2016.

Dicker, Georges. Descartes: An Analytic and Historical Introduction. OUP, 2013.

García-Valverde, José Manuel, and Peter Maxwell-Stuart. Gómez Pereira's Antoniana Margarita (2 Vols): A Work on Natural Philosophy, Medicine and Theology. Brill, 2019. 
Ghazalyat-e Shams-e Tabriz. Selected Ghazals by Jalál-al-Din Mohammad of Balkh (Rumi) A.H. 604-772/AD 1207-1273. Edited by Kadkani M.R.S. Vol. II. Tehran: Sokhan Publishers, 1999.

Gorgin, and Esfehani. "Evolution of the Humankind Based on Theory of 'Soul Being Generated from the Matter and Perpetuating as Spirit." Journal of Religious Thought of Shiraz University, Ser. 50, (Spring 2014), 14, no. 1 (n.d.).

Harre, Rom. Social Being 2e. 2 edition. Oxford, UK ; Cambridge, Mass., USA: John Wiley \& Sons, 1993.

Hossein, Ghomshei Elahi. In the Realm of 365 Poems and Discourses from Rumi. Tehran: Sokhan Publishers, 2012.

Jalaluddin Mohamad, Balkhi. Maulana Fihe Ma Fihe; Moqhadema, Tashib Wa Taliqhat, Doctor Bahman Nehzat. Tehran: Entesharat e Sokhan, 2016.

Jalaluddin Rumi, Molawi. Silent Words, a Selection of Poetry and Prose, Translated by R.A. Nicholson \& A.J. Arbery. Tehran: Hermes Publishers in collaboration with The Centre for Dialogue among Civilisation, 2004.

Jami, Abdurrahman bin Ahmad. Haft Awrang. Tehran: Entesharat e Mahtab, 2003.

Khosraw, N. Gozidah-e Diwan-e Nasser Khosraw. 1st ed. Tehran: Mosese Entesharat e Qhadyani, 1998.

Mohammad bin Mohammad, Ghazali. Gozidah- e Kimyaye Sa'adat. 4th Edition. Tehran: Mosese Entesharat e Qhadyani, 2013.

Peter, Adamson, and Taylor Richard C. Black Deborah. Psychology: Soul and Intellect in The Cambridge Companion to Arabic Philosophy. Cambridge: Cambridge University Press, 2005.

Qaznavi Abolmajd Majdoud ibne Adam, Sanai-e-. Hadiqat-Ol-Haqiqat va Shariat-OlTariqat. 8th Edition. Tehran: University of Tehran Press, 2015.

"Quran," n.d. www.al-quran.info.

Rumi, Jalaluddin. Selected Poems from the Divan-e-Shams-e Tabrizi Edited and Translated by Reynold Alleyne Nicholson. Maryland: IBEX Publishers Bethesda, 2001.

Rumi-Balkhí, Jallaluddin Mohammad. Masnawi e Ma'nawí, Based on Qoniya MSS, Dated 677 H, Edited by Kázem Bargnaysi. Vol. I \& II. Tehran: Fekr e Roz, 2010. 
Homayun Shahpesandy

Scott, John, and Oxford University Press. A Dictionary of Sociology. 4th ed. Oxford: Oxford University Press, 2014.

Sina, Ibn. Fin Nafs-al Ardiya Was-Samawiya, Bakhshayeshi J.F. Vol. 1. Tehran: Entesharat e Ayat Ashraqh, 2012.

- Taheri, S.M. A Translation of Seventeen Essays from The Collected Essays. Translation. Tehran: Entesharat e Ayat Ashraqh, 2009.

Störig, H. J. Kleine. Weltgeschichte Der Philosophie (Malé Déjiny Filozofie). Czech Translation, Čtvrté Vydání. Praha: Zvon. České katolické nakladatelství, 1995.

- Weltgeschichte Der Philosophie (Malē Déjiny Filozofie), Cžech Translation. Zvon. Praha: České katolické nakladatelství, 1991. 